ИСПОЛЬЗОВАНИЕ ИНФОРМАЦИОННЫХ ТЕХНОЛОГИЙ В ПРОЦЕССЕ ИЗУЧЕНИЯ ИНОСТРАННОГО ЯЗЫКА

\author{
DOI: $10.31618 /$ ESU.2413-9335.2020.7.70.576 \\ Арипова Муборак Абдусаттаровна \\ стариий преподаватель \\ Государственной общеобразовательной спещиализированной \\ школьы филологического направления, \\ Узбекистан
}

\title{
USE OF INFORMATION TECHNOLOGIES IN THE PROCESS OF STUDYING A FOREIGN LANGUAGE
}

\author{
Aripova Muborak Abdusattarovna \\ Senior Lecturer, \\ State Specialized School of Philology, \\ Uzbekistan
}

\section{АННОТАЦИЯ}

В статье рассматриваются вопросы об использовании информационных технологий в процессе изучения иностранного языка, о его принципах, о разнообразии инструментов языкового обучения, ключевых моментах в обучении лексике, чтении, аудировании и говорении, о сферах использования информационных технологий, о ее преимуществах и недостатках.

\section{ABSTRACT}

The article discusses the use of information technology in the process of learning a foreign language, its principles, the diversity of language learning tools, key points in teaching vocabulary, reading, listening and speaking, the areas of use of information technology, its advantages and disadvantages.

Ключевые слова: информационные технологии, иностранный язык, языковое обучение, Интернет.

Key words: information technology, foreign language, language training, Internet.

Языковые проблемы сегодня не менее актуальны. В последнее время столь велик интерес к тем образовательным моделям, педагогическим инновациям, технологиям и методам, которые оказываются наиболее эффективными для данной цели. Это приводит к тому, что современные студенты лучше воспринимают и усваивают новую информацию через контакт с компьютерными информационными источниками применение компьютеров в процессе обучения регламентировано требованиями, предъявляемыми к техническим устройствам, и должно соответствовать определенным принципам.

В компьютерной лингводидактике релевантными считаются следующие принципы использования ТСО: обусловленности, необходимости, информативности, надежности. Существуют две основные области применения компьютеров в обучающей деятельности: компьютерная поддержка традиционного обучения и обучение, реализуемое с помощью компьютера, что непосредственно обусловлено повышать качество обучения иностранному языку.

Использование компьютера на занятиях иностранного языка невозможно представить без таких аутентичных языковых материалов, как видео клипы, флэш анимации, новости и т.д. В последнее время стало модным общение студентов с носителями иностранного языка через e-mail, социальные сети. Возможность организации голосовых и видео конференций. Такая онлайн среда - это коммуникация между преподавателем и студентом, студентов друг с другом.
Разнообразие инструментов языкового обучения (онлайн приложения и программы) помогают студентам лучше изучить фонетику, произношение, пополнить лексический запас, освоить грамматические правила и уметь анализировать предложения. Инструменты включают в себя упражнения «от текста к речи», распознавание речи, интерактивные и контролируемые задания. Все это можно применять в игровой форме.

Сейчас имеется большое разнообразие современных мультимедийных учебников, где можно найти достаточно упражнений для обучающихся всех возрастов и разных уровней знаний. Большую помощь в проведении фонетических зарядок оказывает учебная программа «Профессор Хиггинс» «Английский без акцента» и также ряд других мультимедийных учебников. Звуки, слова, словосочетания и предложения воспринимаются обучающимися на слух и зрительно. Обучающиеся имеют возможность наблюдать на экране компьютера за артикуляционными движениями и воспринимать на слух правильную интонацию. Тексты для аудирования на страноведческие темы в средних и старших классах можно подобрать из мультимедийного учебника «Английский базовый курс», в котором около 60 текстов на различные темы по истории, культуре и быту Великобритании и США. Тексты эти довольно интересные и содержательные.

Рассмотрим параметры изучения иностранного языка. 
Так, при обучении лексике необходимо формировать рецептивные лексические навыки чтения и аудирования, а также продуктивные лексические навыки преимущественно в письменной речи, где можно предложить эссе или проект. Осуществление контроля за уровнем сформированности лексических навыков на основе тестовых и игровых компьютерных программ, используя визуальную наглядность. При расширении использования пассивного и потенциального словарей, обучаемых приходят на помощь автоматические словари, программы подбора синонимов и антонимов.

При обучении чтению формируются навыки установления звукобуквенных соответствий, отрабатывается техника чтения вслух, за счет применения таких приемов, как варьирование поля восприятия и темпа предъявления, изменение расположения текста и т.д. Обучающиеся овладевают умениями извлечения из текста смысловой информации различных видов (основной, второстепенной, уточняющей и т.д.), самостоятельно преодолевают языковые трудности, умеют контролировать правильно понимание прочитанного текста, а при обучении аудированию еще и прослушанного текста.

Важным моментом при обучении говорения является формирование фонетических навыков говорения. Такое общение проходит в форме парной работы или в небольших группах с использованием ролевых игр на базе симулятивномоделирующих программ

Одним из основных требований, предъявляемых к обучению иностранным языкам с использованием интернет-ресурсов, является создание взаимодействия на уроке, что принято называть в методике интерактивностью. Интерактивность - это «объединение, координация и взаимодополнение усилий коммуникативной цели и результата речевыми средствами».

Широкая сфера использования информационных технологий таких как: 1. для поиска литературы а) в электронном каталоге библиотеки учебного заведения; б) в сети Internet c применением браузеров типа Internet Explorer и др., различных поисковых систем (Yandex.ru, Rambler.ru, Mail.ru, Google.ru, Search.com, Yahoo.com и т.д.); 2. для работы с литературой в ходе реферирования, конспектирования, аннотирования, цитирования и т.д.; 3 . для автоматического перевода текстов с помощью программ-переводчиков, с использованием электронных словарей; 4. для хранения и накопления информации (CD-, DVD-диски, Flashкарты); 5. для общения (Internet, электронная почта); 6. для обработки и воспроизведения графики и звука (проигрыватели Microsoft Media Player, WinAmp, WinDVD, программы для просмотра изображений PhotoShop, Corel Draw, программы для создания схем, чертежей и графиков), создания учебных и воспитательных фильмов, мультфильмов, роликов, обучающих компьютерных программ, игр, интерактивных путешествий, энциклопедий и т.д.; 7. для пропаганды и внедрения результатов исследования (выступления в видеофорумах, телемостах, публикации в СМИ, сети Интернет).

Компьютерные формы изучения языка должны быть частью смешанного обучения, которое охватывает контролируемое изучение, формальное и неформальное. Имея ограниченное количество аулиторных часов, необходимо расширять формы работ, которые студенты смогут выполнять вне занятий.

Частой ошибкой при использовании компьютерных технологий в процессе обучения является постоянное сидение обучаемых у компьютера, злоупотребление компьютерными эффектами, избыточность красок, зачастую готовые учебные компьютерные программы по предмету очень сложно адаптировать к традиционному уроку, поскольку они не всегда соответствуют рабочей программе дисциплины, методическим целям и дидактическим принципам в обучении.

Итак, компьютерные технологии помогают:

- привлекать пассивных слушателей;

- делать практические занятия более наглядными;

- обеспечивать учебный процесс новыми, ранее недоступными материалами, которые помогают студентам проявлять их творческие способности;

- приучать обучающихся к самостоятельной работе с материалом;

- обеспечивать моментальную обратную связь;

- объективно оценивать действия обучающихся;

- реализовывать личностно-ориентированный и дифференцированный подходы в обучении;

\section{Литература:}

1.Полат Е. С., Бухаркина М. Ю., Моисеева М. В., Петров А. Е. Новые педагогические и информационные технологии в системе образования. - М., 2001

2.Карамышева Т. В. Изучение иностранных языков с помощью компьютера. В вопросах и ответах. - СПб.: Издательство «Союз», 2001. $192 \mathrm{c}$.

3.Полат Е.С. Интернет на уроках иностранного языка// ИЯШ № 2, 32008 г.

4.Полилова Т.А., Пономарева В.В. Внедрение компьютерных технологий в преподавание иностранных языков. // ИЯШ. - 1997. - №6. 